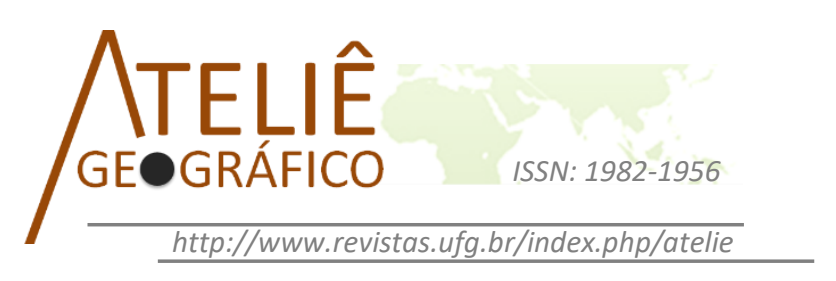

\title{
A configuração da Ferrovia Norte-Sul e os desdobramentos socioespaciais nas mesorregiões Centro e Norte de Goiás
}

\author{
The configuration of the Ferrovia Norte-Sul and the socio- \\ spatial unfoldings in the Central and Northern Meso-regions \\ of Goiás, Brazil
}

La configuración de la Ferrovía Norte-Sur y los desdoblamientos socioespaciales en las Mesorregiones

Centro y Norte de Goiás

\author{
Lara Cristine Gomes Ferreira \\ Universidade Federal de Goiás \\ laracristineufg@yahoo.com.br \\ Caio César Alencar de Sena \\ Universidade Federal de Goiás \\ caiosenageo@gmail.com
}

\begin{abstract}
Resumo
Este estudo aborda a logística dos transportes em Goiás com ênfase nos desdobramentos socioespaciais provocados pela Ferrovia Norte-Sul. Para tanto, analisa-se a produção e os investimentos nas mesorregiões Centro e Norte do estado. O objetivo central é compreender o papel da Ferrovia em questão no contexto do Programa de Aceleração do Crescimento (PAC), que tem promovido a reestruturação dos territórios, do escoamento e da circulação da produção moderna capitalista. Quanto ao aporte metodológico, foram realizadas revisões bibliográficas, análise do projeto da Ferrovia, levantamento de dados primários via trabalho de campo e dados secundários em instituições de pesquisa e estatística, espacialização de dados em mapas, tabulação e análise de gráficos e tabelas para então ponderação de cenários. Conclui-se que a ampliação das infraestruturas de transportes é fundamental para a modernização dos territórios e dialoga diretamente com o modelo de produção vigente. No entanto, mesmo que essas infraestruturas e a própria produção recebam investimentos do Estado, o uso da Ferrovia está atrelado aos grandes produtores do agronegócio e da mineração das mesorregiões estudadas. Dessa forma, o pequeno produtor e o transporte de pessoas, ficam, novamente, em segundo plano.

Palavras-chave: Escoamento da produção, Redes e transportes, Centro e Norte de Goiás, Logística ferroviária.
\end{abstract}




\begin{abstract}
This study deals with transport logistics in Goiás, with emphasis on the socio-spatial unfolding provoked by the Norte-Sul Railway. For that, the production and the investments in the Center and North mesoregions of were analyzed. The main objective is to understand the role of the Railway in the context of the 'Programa de Aceleração do Crescimento (PAC)', which has promoted the restructuring of territories, flow and circulation in modern capitalist production. For the methodological input, bibliographical revisions were carried out; railroad project analysis, primary data collection through field work and secondary data in research and statistical institutions; spatialization of data in maps; tabulation and analysis of graphs and tables for then weighting of scenarios. In conclusion, the expansion of transport infrastructures is fundamental for the modernization of the territories and dialogues directly with the current production model. However, even if these infrastructures and the production itself receive investments from the State, the use of the Railroad is directed to the great agribusiness and mining producers of the studied mesoregions. In this way, the small producer and the transportation of people, are again in the background.
\end{abstract}

Keywords: Production Circulation, Networks and transport, Central and North of Goiás, Railway logistics.

\begin{abstract}
Resumen
Este estudio aborda la logística de los transportes en Goiás con énfasis en los desdoblamientos socioespaciales provocados por la Ferrovía Norte Sur. Para ello, se analiza la producción y las inversiones en las mesorregiones Centro y Norte del estado. El objetivo central es comprender el papel de la Ferrovía en cuestión en el contexto del Programa de Aceleração do Crescimento (PAC), que ha promovido la reestructuración de los territorios, del flujo y de la circulación de la producción moderna capitalista. En cuanto al aporte metodológico, se realizaron revisiones bibliográficas; análisis del proyecto de Ferrovia; levantamiento de datos primarios vía trabajo de campo y datos secundarios en instituciones de investigación y estadística; espacialización de datos en mapas; tabulación y análisis de gráficos y tablas para entonces ponderación de escenarios. Se concluye que la ampliación de las infraestructuras de transporte es fundamental para la modernización de los territorios y dialoga directamente con el modelo de producción vigente. Sin embargo, aunque estas infraestructuras y la propia producción reciban inversiones del Estado, el uso de Ferrovia está vinculado a los grandes productores del agronegocio y de la minería de las mesorregiones estudiadas. De esta forma, el pequeño productor y el transporte de personas, quedan, nuevamente, en segundo plano.
\end{abstract}

Palabras clave: Circulación de la producción, Redes y transportes, Centro y Norte de Goiás, Logística ferroviaria.

\title{
Introdução
}

Com a visível aceleração contemporânea do tempo e das técnicas, a fluidez, a circulação e as redes tornaram-se exigências básicas do momento atual. Ao mesmo tempo em que as empresas e corporações exigem o mínimo de infraestrutura para sua territorialização, quando estas já estão implantadas, criam-se demandas cada vez mais 
complexas para que a estratégia e o sucesso econômico se efetivem. Para isso, além da ação empreendedora das empresas, o Estado muito contribui para que a circulação da produção, informação e dinheiro aconteça.

Em vias de atuação difusa, muitas vezes ao invés de promover um dinamismo em investimentos e setores econômicos, ou ainda promover o desenvolvimento territorial voltado para um projeto de sociedade, menos concentrado, as ações estatais tendem a direcionar investimentos e a implantação de redes técnicas representando não um projeto de sociedade, mas sim interesses específicos, promovendo um desenvolvimento social incompleto, tal como salientou Castro (1991) ao estudar o planejamento e as ações institucionais.

A fluidez e a circulação da produção estão cada vez mais complexas. É bastante comum que a circulação seja pensada anterior à produção, no sentido de garantir o mercado e não permitir excedentes e prejuízos. Para isso, a fluidez contemporânea é baseada nas redes, que são cada vez mais globais. As redes técnicas, por exemplo, dão o suporte necessário para a competitividade e o sucesso econômico. Concorda-se com Santos (2002), o qual defende que a " [...] fluidez é, ao mesmo tempo, uma causa, uma condição e um resultado" (SANTOS, 2002, p.185).

Portanto, com o decorrer da história, muitas foram as formas de redes criadas pelo ser humano para viabilizar a comunicação e as trocas. As invenções e inovações que visavam ampliar a capacidade produtiva e melhorar a circulação, viabilizaram o surgimento das redes (FRAGA, 2007). Dias (2007) ressalta que as redes não se inscrevem no vazio, mas em espaços geográficos plenos de história. Ele ainda destaca o papel das redes técnicas, tanto na criação de condições sociais inéditas, quanto na estruturação de territórios.

Assim, o estudo das redes tem se tornado bastante relevante na atualidade, sobretudo com o processo de globalização. Parte-se, neste artigo, da premissa de Benakouche (2005), o qual faz um alerta sobre a dimensão política das técnicas. É fundamental entender o papel da técnica de modo integrado, considerando os aspectos socioeconômicos e polítcos e não somente a técnica pela técnica.

Desta forma, toda rede acaba por revelar as tessituras e a implantação dos pontos, bem como um domínio do espaço, da realidade (RAFFESTIN, 1993). Essa afirmação é importante para a reflexão de que inexiste rede isenta das relações de poder, assim como a materialização dos objetos técnicos, que vão formar as redes técnicas, prenhes de intencionalidades, fruto da lógica do mercado nacional ou internacional.

Santos (2006) trouxe a discussão de sistemas técnicos para compreender as transformações no espaço geográfico como um conjunto de técnicas, ferramentas e conhecimentos que permitam a fluidez do território e contribuam para uma maior dinâmica do capital e da produção. 
Neste sentido, será realizada uma abordagem geográfica sobre a logística dos transportes, para o estado de Goiás, dando ênfase às mesorregiões Centro e Norte, sobretudo relacionado à configuração da Ferrovia Norte-Sul e seus desdobramentos socioespaciais. O objetivo central é compreender o papel dessa Ferrovia para Goiás e as microrregiões supracitadas, no que tange à sua expansão, por meio do contexto do Programa de Aceleração do Crescimento (PAC); a reestruturação dos territórios; o escoamento e a circulação da produção capitalista; e os principais cenários de escoamento da produção pela Ferrovia.

Para tanto, foram necessárias as seguintes etapas metodológicas: 1) Revisão bibliográfica sobre a temática das redes geográficas, objetos técnicos, logística, ferrovias, entre outras; 2) Levantamento de dados sobre a formação histórica e de perfil socioeconômico das mesorregiões Centro e Norte do estado de Goiás; 3 ) Levantamento de dados e referências sobre a expansão da Ferrovia Norte-Sul e seus desdobramentos territoriais para Goiás e as mesorregiões em análise; 4) Tabulação, análise dos dados e escrita de textos parciais e finais.

\section{As mesorregiões Centro e Norte de Goiás: formação histórica e perfil Socioeconômico}

As mesorregiões do estado de Goiás foram institucionalmente reconhecidas por meio da Resolução da Presidência $\mathrm{n}^{\circ} 11$, de 5 de junho de 1990 , do Instituto Brasileiro de Geografia e Estatística (IBGE). Essa regionalização possui caráter político e estratégico, bem como leva em consideração características geográficas comuns, que podem pautar ações de planejamentos municipais, estaduais ou regionais.

De acordo com o IBGE, Goiás é dividido em cinco mesorregiões: Centro, Leste, Noroeste, Norte e Sul. Nesta seção do artigo serão destacadas as características socioeconômicas das mesorregiões Centro e Norte goiano, que são formadas por 82 e 27 municípios, respectivamente. Os potenciais de produção do território, sobretudo voltados à mineração e agropecuária, que podem ser compreendidos como as produções de maior interesse e justificativa regional para a ampliação dos serviços logísticos, como os da Ferrovia Norte-Sul, também serão analisados.

A ocupação do Centro e Norte de Goiás e a apropriação do território possuem diversos marcos geo-históricos importantes. Chaul (1997), Teixeira Neto (2008), Estevam (2008) e Castilho (2010) destacam a exploração aurífera do Brasil Colonial; as redes de produção com a estrada de ferro a partir do século XX; a Marcha para o Oeste com a criação da Colônia Agrícola Nacional de Goiás (CANG) na década de 1940 -, e a expansão da fronteira agrícola a partir da década de 1970.

Um elemento central nessa discussão são as ações e incentivos do Estado para a dinamização do território. Acerca deste assunto, Arrais (2013) salienta que as ações estatais são capazes de produzir o território, ao citar investimentos financeiros voltados à 
criação de infraestrutura, financiamento de produção e maquinários, investimentos em escoamento de produção, dentre outros.

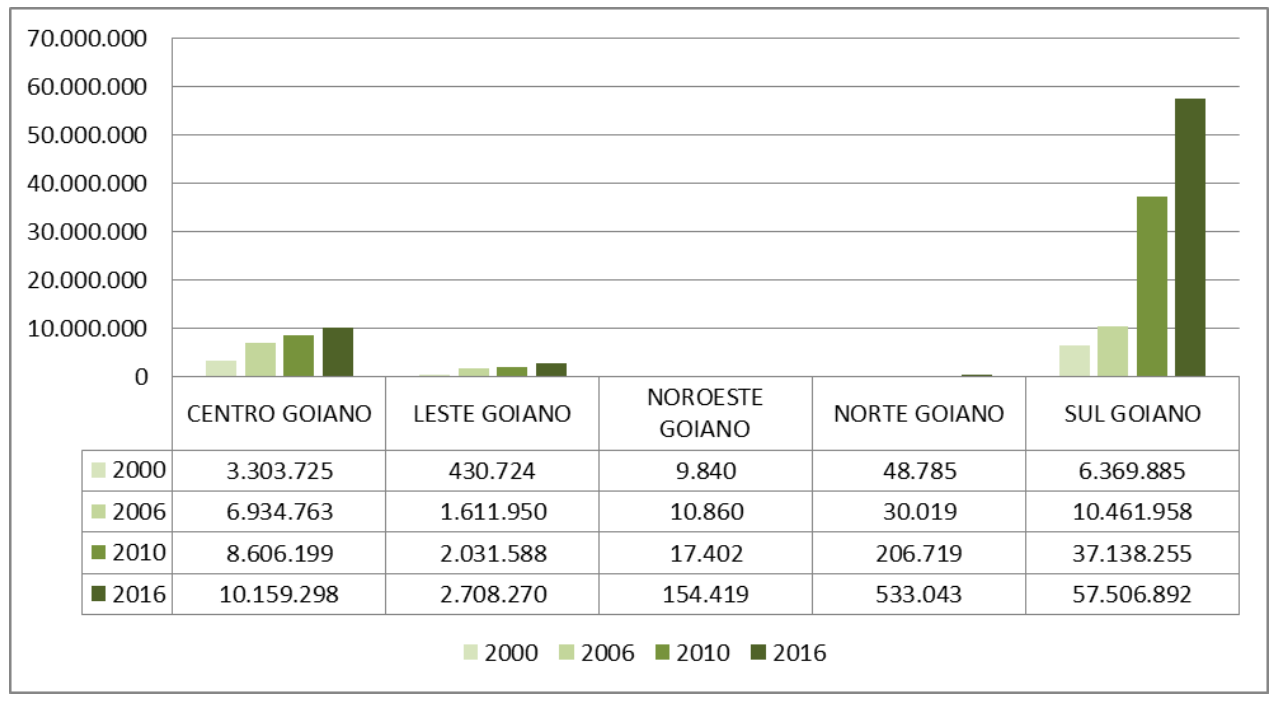

Figura 01. Produção de cana-de-açúcar - Quantidade Produzida (t) / 2000-2016 Fonte: IMB (2017).

Nas duas regiões estudadas é notório que a expansão da produção de cana-deaçúcar, bem como a diversificação de seus derivados de alto poder agregador financeiro são bastante importantes para se pensar no território goiano do presente e do passado, conforme pode ser visualizado na série histórica da Figura 1. Observa-se que a crescente produção canavieira no Centro-Norte goiano tende a necessitar cada vez mais de uma diversificação dos modais de transporte, visando o deslocamento da produção para longas distâncias e para os portos brasileiros e, também, a exportação dos produtos para o mercado externo.

De acordo com o Instituto Mauro Borges (IMB, 2017), todas as regiões de Goiás tiveram significativo aumento na quantidade produzida (em toneladas) de cana-deaçúcar entre os anos 2000 e 2016 (Figura 01). É difícil afirmar, no entanto, que a capacidade de escoamento dessa produção tenha ampliado ou se diversificado na mesma urgência que a produção. Esse fato, aliado aos problemas nas rodovias goianas e nacionais, chama a atenção para a necessidade de se repensar a questão dos transportes. Tanto no que toca ao escoamento da produção para o agronegócio como no que diz respeito à exemplificação da produção de grãos e cana-de-açúcar e ao transporte de pessoas; um desafio que parece estar ainda mais distante de ser solucionado ou ao menos colocado em pauta quando se analisa o contexto regional. 
Como mencionado, alguns derivados da cana-de-açúcar destinam-se à exportação, destacam-se o açúcar (açúcar cristal e orgânico) e a levedura hidrolisada e autolisada. As leveduras são microrganismos responsáveis pela fermentação alcoólica, transformando o açúcar da cana em etanol. O processo de produção da levedura utiliza portanto, o excedente da fermentação alcoólica como matéria-prima. A levedura é utilizada sobretudo como suplemento nutritivo nas fórmulas de ração animal (rações de aves, suínos, bovinos, caprinos, peixes, camarões, equinos, cães, gatos e outros), principalmente por apresentar um alto teor de proteína, além de elevada concentração de vitaminas do Complexo B e excelente balanço de aminoácidos ${ }^{1}$.

Dentre as regiões goianas com maior produção canavieira, o Centro Goiano destaca-se como a segunda maior produtora, atrás somente do Sul Goiano. Dentre a série histórica analisada, o Centro Goiano teve um crescimento de cerca de 207,5\%, passando de 3.303.725 (t) produzidas em 2000, para 10.159.298 (t) em 2016 (Figura 1). A terceira região que mais produziu cana-de-açúcar foi o Leste Goiano, seguida do Norte Goiano, que aumentou a produção de 48.785 (t) em 2000 para 533.043 (t) em 2016.

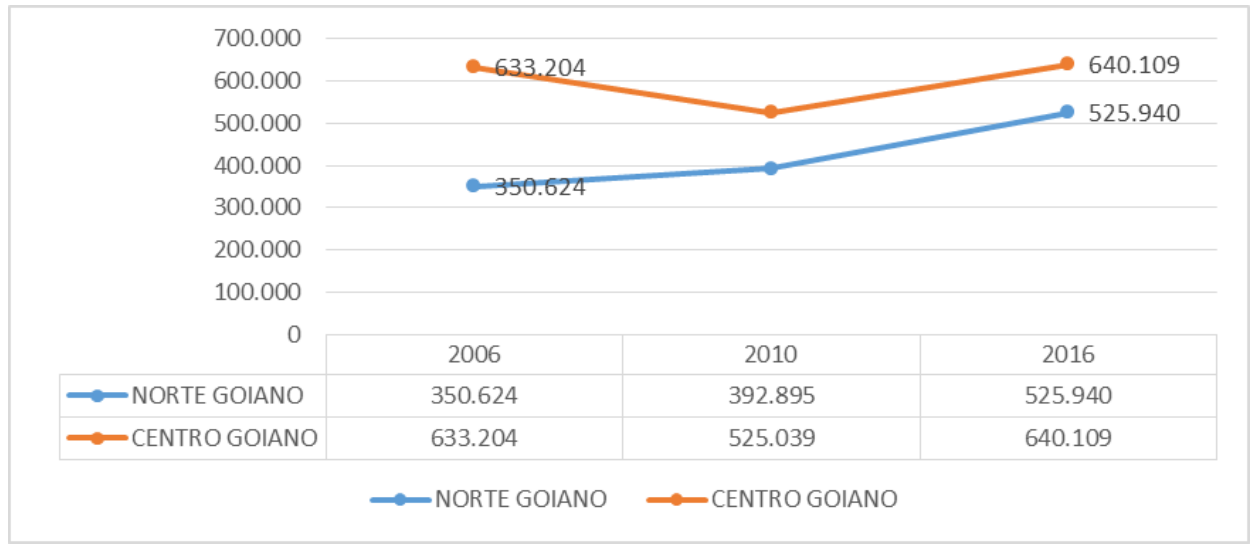

Figura 02. Produção de grãos - Quantidade Produzida (t) / (2006-2016) Fonte: IMB (2017).

O estado de Goiás também é um grande produtor e exportador de grãos. Na Figura 2 pode-se verificar a produção de grãos em Goiás no intervalo de 2000 a 2016. A produção de grãos em Goiás também integra o conjunto de produtos do agronegócio, sendo uma das principais commodities brasileiras. Neste ponto, cabe salientar que as produções goianas voltadas ao mercado agroexportador teriam na Ferrovia Norte-Sul um

\footnotetext{
1 A usina Jalles Machado, localizada no município de Goianésia, no Centro goiano, produz e exporta a levedura para o mercado internacional. Disponível em: <https://www.jallesmachado.com/pt/produtos/levedura>. Acesso em: 05 maio 2018.
} 
importante meio de transporte e logística, com menos perdas e mais rapidez no deslocamento aos portos brasileiros.

Em relação à produção de grãos, as regiões estudadas representam a terceira e a quarta mesorrregiões que mais produzem grãos no estado de Goiás, assim como ocorre com a produção de cana-de-açúcar. De acordo com a Figura 2, observa-se em 2010 um período de queda de produção no Centro goiano, seguido de um crescimento na produção no ano de 2016. Já a região Norte goiano apresentou crescimento em todo período analisado.

Goiás também possui destaque na produção de alguns minérios para o mercado internacional. $\mathrm{Na}$ Tabela 1, pode-se observar os principais minérios produzidos em Goiás e nas regiões estudadas. Ressalta-se que alguns desses minérios também poderão ser transportados via Ferrovia Norte-Sul.

Tabela 1. Principais produções minerais: Regiões Centro, Norte e estado de Goiás

\begin{tabular}{|c|c|c|c|c|}
\hline & & 2006 & 2010 & 2016 \\
\hline \multirow{4}{*}{$\begin{array}{c}\text { ESTADO } \\
\text { DE GOIÁS }\end{array}$} & Produção de Água Mineral (1) & 74.417 .392 & 126.137 .113 & 183.719 .813 \\
\hline & Produção de Brita & 2.286 .166 & 7.160 .077 & 6.536 .825 \\
\hline & Produção de Calcário Agrícola (t) & 1.594 .028 & 3.036 .512 & 4.846 .495 \\
\hline & $\begin{array}{l}\text { Produção de Calcário para } \\
\text { Cimento }\end{array}$ & 912.774 & 1.623 .177 & 1.407 .755 \\
\hline \multirow{6}{*}{$\begin{array}{l}\text { CENTRO } \\
\text { GOIANO }\end{array}$} & Produção de Água Mineral (1) & 60.424 .047 & 111.261 .530 & 115.376 .625 \\
\hline & Produção de Areia $\left(\mathrm{m}^{3}\right)$ & 106.190 & 316.238 & 267.638 \\
\hline & Produção de Brita & 1.762 .524 & 4.201 .833 & 2.986 .808 \\
\hline & Produção de Níquel (t) & 10.087 & 32.804 & 35.500 \\
\hline & Produção de Rochas Ornamentais & 3.009 & 3.335 & 2.019 \\
\hline & Produção de Vermiculita (t) & 18.415 & 60.125 & 51.557 \\
\hline \multirow{6}{*}{$\begin{array}{c}\text { NORTE } \\
\text { GOIANO }\end{array}$} & Produção de Água Mineral (1) & - & 102.480 & 310.540 \\
\hline & Produção de Amianto (t) & 227.304 & 304.569 & 177.677 \\
\hline & Produção de Areia $\left(\mathrm{m}^{3}\right)$ & 68.606 & 92.304 & 40.393 \\
\hline & Produção de Calcário Agrícola (t) & 28.821 & 184.275 & 125.568 \\
\hline & Produção de Cobre (t) & 4.490 & 72.964 & 53.000 \\
\hline & Produção de Níquel (t) & 21.630 & 32.373 & 15.115 \\
\hline
\end{tabular}

Fonte: IMB (2017).

De acordo com a Tabela 1, destacam-se em Goiás a produção de água mineral, brita, calcário agrícola e para cimento. Quanto ao Centro Goiano, as principais produções minerais são a água mineral, areia e brita, com destaque para o ano de 2010. No Norte Goiano é muito expressiva a produção de Amianto e Areia, nessa região a produção de água também é importante, porém sem registros no IMB (2006). Também são produzidos nas duas regiões destacadas rochas ornamentais e vermiculita (Centro Goiano); calcário agrícola, cobre e níquel (Norte Goiano). Nota-se pela análise geral das produções, que em muitos casos as explorações não são uniformes, observa-se uma 
crescente produção mineral, porém com muitos casos de recuo de produção entre um ano de outro, algumas vezes seguidos por outro aumento.

O crescimento da produção mineral nas duas regiões citadas (Centro e Norte), na maior parte dos elementos apontados anteriormente, repercute também no aumento do Produto Interno Bruto (PIB) e ainda no PIB per capita. O aumento de PIB verificado na Figura 03, na maioria das vezes impulsionado por empresas privadas amparadas pelo Estado, dificilmente repercute em um desenvolvimento social local. Isso porque, conforme afirmou Santos (2011), a pobreza é planejada por atores econômicos e hegemônicos que possuem o apoio do Estado.

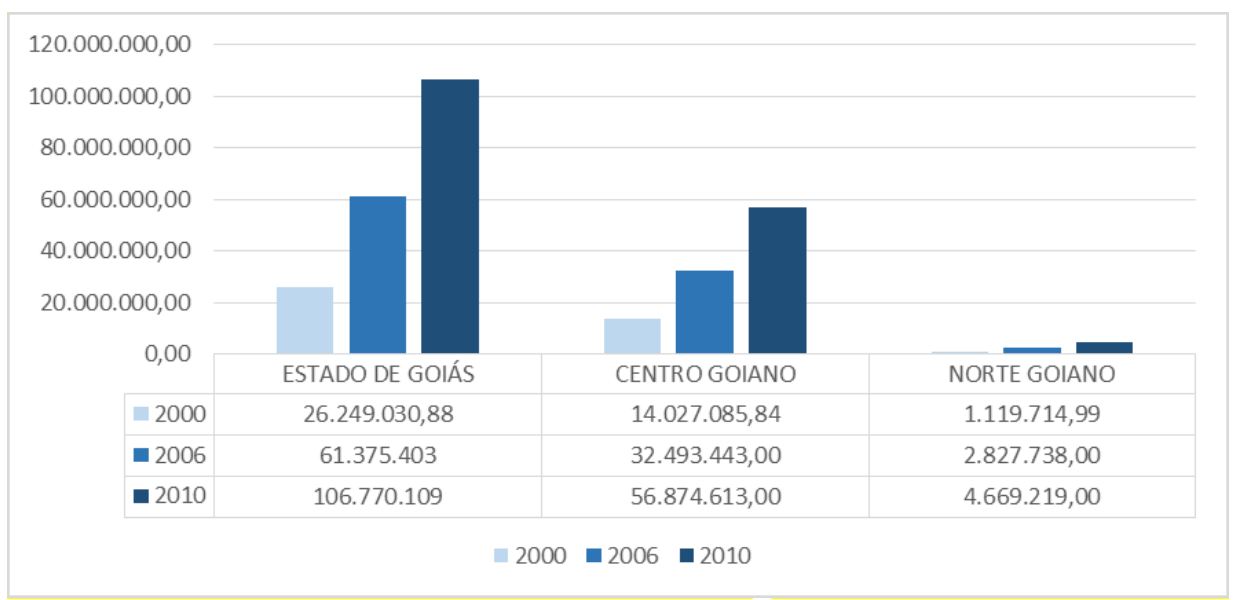

Figura 03. Produto Interno Bruto a Preços Correntes - PIB (R \$ mil) / (2000-2010) Fonte: IMB (2017).

Observa-se também na Figura 3 que o PIB do estado de Goiás a Preços Correntes (R\$ mil) passou de 26.249 (bilhões) em 2000 para 106.770 ((bilhões) em 2010. Esse aumento também foi observado no Centro Goiano, que passou de 14.027 (bilhões) para 56.874 (bilhões), e de 1.219 (bilhões) em 2000 para 4.669 (bilhões) em 2010 no Norte Goiano. Apesar dos números indicarem crescimento da economia, tal crescimento é direcionado para setores específicos, geralmente os mesmos amparados pelo Estado anteriormente. Parte dessa produção que auxilia no crescimento do PIB relaciona-se com as atividades agropecuárias e minerais, que de acordo com o IMB (2017) são destaques na produção de commodities para exportação, sendo que, historicamente, em média, 75\% das exportações goianas são compostas por produtos ligados ao complexo grãos-carnes e minérios.

Tanto no estado de Goiás quanto no cenário nacional, os setores econômicos que mais contribuem com o PIB são amparados com políticas de investimentos públicos. No âmbito nacional, os investimentos públicos em setores privados ficam bastante demarcados pelas ações do Banco Nacional de Desenvolvimento 
Econômico e Social (BNDES). Em Goiás foram importantes o Fundo de Participação e Fomento à Industrialização de Goiás (FOMENTAR), criado pelo Governo Estadual em 1984 e que tinha como objetivo central atrair grandes empresas e indústrias para Goiás, com base na isenção temporária do pagamento de 70\% sobre o Imposto sobre Circulação Mercadorias e Serviço (ICMS). E, mais adiante, em 2000, foi criado o Programa de Desenvolvimento Industrial de Goiás (PRODUZIR) que, primeiramente, teve a intenção de substituir o FOMENTAR, com prazo de duração de 10 anos, mas acabou sendo prorrogado para o ano 2020 (FERREIRA, 2016).

Na próxima seção será ampliada a discussão sobre o papel do Estado como agente regulador e financiador de certos objetos técnicos e como o modal ferroviário tem apresentado expansão ao longo dos últimos anos, bem como um breve estado da arte sobre a Ferrovia Norte-Sul.

\section{A Ferrovia Norte-Sul no contexto do Programa de Aceleração do Crescimento (PAC)}

A construção de rodovias e ferrovias foi muito importante para o processo de ocupação demográfica, expansão da fronteira agrícola e valorização econômica dos lugares. Ao longo do tempo são inúmeros os exemplos de povoados e cidades que foram criadas por meio da abertura de estradas, acompanhadas geralmente de um considerável desenvolvimento regional. Para Martins (1997), a abertura de estradas em determinada localidade era algo extremamente significativo, pois consistia em uma nova fase da expansão da fronteira agrícola no país e representava a chegada dos processos civilizatórios. Com a construção de estradas um novo tipo de economia se apresentava, uma economia voltada a atender o mercado, vinculada a circulação e escoamento da produção, em substituição a uma economia de subsistência.

A partir da década de 1950 alguns programas incentivaram a política de integração nacional, com expansão sobretudo para o Centro-Norte do Brasil, o que ocasionou uma intensificação na construção da malha viária na busca de integração econômica à região Sudeste do Brasil, bem como assegurou o intercâmbio nacional à capital federal, Brasília.

Após esse efervescente contexto de integração nacional, principalmente entre os anos 1950 a 1970, o Brasil ficou por muito tempo sem grandes programas relacionados à rede de transportes, o que o deixou visivelmente à margem das reais necessidades de circulação e às novas lógicas impostas por um período de extrema demanda global, principalmente por meio das corporações internacionais implantadas no país. Assim, na tentativa de ampliar a infraestrutura de transportes e readequá-la às novas exigências, $\mathrm{o}$ Governo Federal lançou, em 2007, o Programa de Aceleração do Crescimento (PAC) e o Programa de Investimentos em Logística (PIL) e a participação na iniciativa para a integração da Infraestrutura Regional Sul-Americana (IIRSA). 
Em síntese, o PAC foi pensado como um plano estratégico de resgate do planejamento e de retomada dos investimentos em setores estruturantes do país, que acabou contribuindo para a elevação do investimento público e privado em obras de infraestrutura e logística. Segundo Jardim e Silva (2015), as ações do PAC estão sustentadas nas seguintes estratégias:

- Uma programação maciça de investimentos em infraestrutura logística (rodovias, ferrovias, portos etc.), geração de energia e infraestrutura social (saneamento e habitação), com grande participação das empresas estatais e bancos públicos;

- Um conjunto de incentivos tributários (exonerações fiscais a setores e bens específicos) e financeiros (expansão e redução do custo do crédito para investimento) ao setor privado, complementado por arranjos institucionais voltados para o estabelecimento de regras estáveis e condições de segurança jurídica ao investimento privado na indústria e na infraestrutura;

- Um arranjo de compromissos da política físcal e monetária até 2010 (cujo elemento central é a redução progressiva da taxa básica de juros da economia), tendo em vista viabilizar o financiamento do programa de investimento público (pela, entre outras coisas, redução do superávit primário e da velocidade de crescimento dos gastos com pessoal) e tornar consistente em termos macroeconômicos o programa de crescimento, o dispêndio público e a estabilização de preços.

De acordo com o $6^{\circ}$ Balanço do PAC (2015-2018), o programa alcançou, até 31 de dezembro de $2017,87,1 \%$ do total previsto para o período $2015-2018$, saindo de $\mathrm{R} \$$ 386,6 bilhões, realizados até dezembro de 2016, para R \$ 547,5 bilhões. Ainda segundo esse documento, os investimentos na expansão do sistema ferroviário buscam escoamento mais eficiente dos produtos destinados à exportação, o que deve ampliar a participação e a competitividade do País no comércio internacional, além de reduzir os custos de logística. No total, $3.457 \mathrm{~km}$ de novas ferrovias estão em obras, com destaque para implantação da Extensão Sul da Ferrovia Norte-Sul (FNS), com 685 km e com avanço de 93,2\%; e para a Ferrovia de Integração Oeste Leste (FIOL), com 1.022 km e $72,4 \%$ de suas obras concluídas no trecho entre Ilhéus e Caetité.

Para o presente artigo, conforme já mencionado, será dado foco na Ferrovia Norte-Sul, cuja construção foi iniciada em 1987, com um traçado inicial que previa uma extensão de aproximadamente $1.550 \mathrm{~km}$, do município de Açailândia (MA) ao município de Anápolis (GO), de modo a cortar os estados do Maranhão, Tocantins e Goiás. O projeto de ampliação da Ferrovia ocorreu muito depois do início da sua construção. A Lei ${ }^{\circ}$ 11.297, de 09 de maio de 2006, da Presidência da República, incorporou um trecho mais ao norte, Açailândia (MA) - Barcarena (PA), ao projeto do traçado inicialmente projetado. Em 2008, a Lei $\mathrm{n}^{\circ} 1.772$ estendeu mais uma vez o traçado da ferrovia até a cidade paulista de Panorama (VALEC, 2018).

A Ferrovia Norte-Sul, quando concluída, possuirá uma extensão de 4.155 quilômetros e passarrá pelos estados do Pará, Maranhão, Tocantins, Goiás, Minas 
Gerais, São Paulo, Mato Grosso do Sul, Paraná, Santa Catarina e Rio Grande do Sul. Atualmente, seu traçado efetivo vai de Açailândia (MA) a Estrela d'Oeste (SP). Porém, apenas o trecho entre Açailândia (MA) e Porto Nacional (TO) está totalmente operacional, sob responsabilidade da concessionaria VLI. Já o trecho entre Porto Nacional (TO) e Anápolis (GO), teve sua obra concluída no ano de 2014. Por fim, o trecho entre Ouro Verde de Goiás (GO) e Estrela d'Oeste (SP) segue em fase final de obras, sob responsabilidade da Valec. A extensão Norte, até o estado do Pará, e a extensão Sul, até o estado do Rio Grande do Sul, continuam em fase de projeto. A Figura 04 mostra o traçado da Ferrovia Norte-Sul e suas fases 'em andamento' e 'concluídas'.

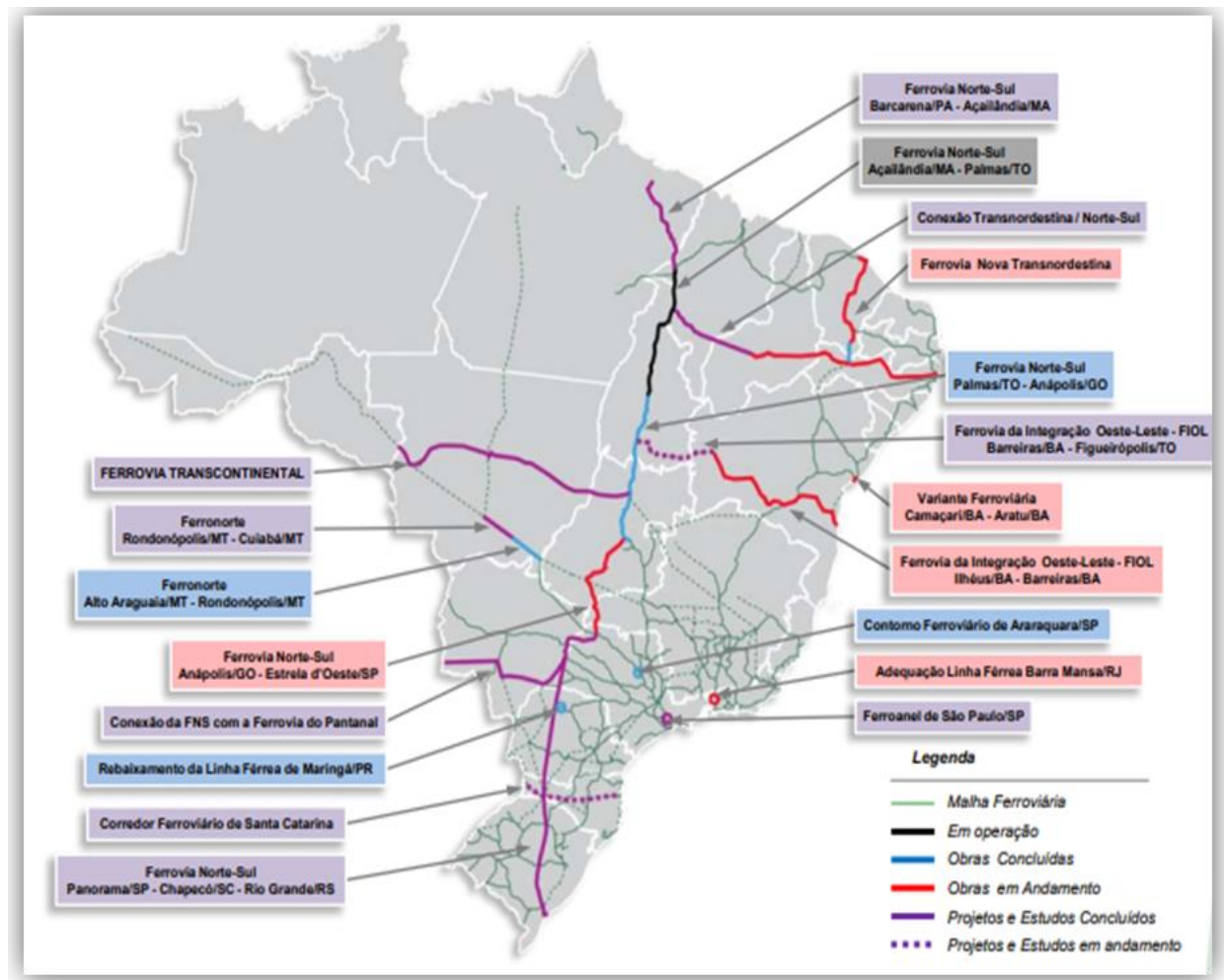

Figura 04. Mapa do traçado da Ferrovia Norte-Sul e suas fases de implantação.

Fonte: Ministério do Planejamento, Desenvolvimento e Gestão (2018).

O investimento em logística de circulação e escoamento da produção é fundamental para a redução dos gastos em transportes, o que influencia diretamente na competitividade do comércio internacional brasileiro, já que gastos muito altos em transporte influenciam na redução da produtividade e rentabilidade econômica. Em relação ao estado de Goiás, mesmo apresentando certa deficiência na logística de 
transportes, algumas regiões apresentam melhores condições de escoamento da produção, o que contribui para a efetivação da dinâmica econômica.

Assim, os transportes têm papel fundamental para a implantação de indústrias e escoamento da produção agronegocista em Goiás, pois a evolução da rede de transportes permitiu uma maior acessibilidade a todas as fontes e a todos os mercados, tornando o espaço muito mais flexível. Assim, de acordo com Fischer (1978) com a evolução dos transportes, a indústria adquiriu uma liberdade muito maior para a implantação de suas unidades no espaço geográfico.

De modo geral, o sistema de integração, por intermédio dos transportes, ainda é ineficiente em Goiás, principalmente quando se pensa na rede ferroviária. Com o PAC houve um maior investimento em ferrovias, mas ainda a fluidez do território por esse modal encontra-se nas mãos da iniciativa privada, como bem refletiu Arrais (2013), já que algumas agroindústrias, principalmente beneficiadoras de grãos (no caso goiano), possuem ferrovias integradas a elas.

Contudo, é muito importante se ater à lógica de expansão das redes técnicas e ao papel do Estado, especialmente vinculado aos interesses político-financeiros existentes. Segundo Fischer (1978), a ferrovia tem um papel histórico no processo de industrialização e é tecnicamente eficaz para a circulação em médias e grandes distâncias, além de possibilitar o transporte de vários tipos de mercadoria. Diante disso, reitera-se que a expansão da malha ferroviária brasileira obedece a uma lógica espacial, que se vincula ao escoamento de produtos estratégicos e importantes para a economia brasileira. Isso será ponto de discussão na próxima seção.

\section{A Ferrovia Norte-Sul em Goiás: cenários de escoamento da produção}

Nos últimos anos, tem-se retomado a expansão da malha ferroviária brasileira, principalmente por meio do investimento de programas federais como o PAC. Segundo Castilho e Arrais (2017), essa expansão se apresenta tardia porque vem ocorrendo justamente no momento em que a produção e exportação esbarra na ineficiente infraestutura logística brasileira.

Parte-se aqui da premissa que, há uma intencionalidade, tanto para a determinação dos objetos técnicos a serem implantados, como na utilização dos mesmos, conforme Santos (2002). Ainda segundo esse autor, não se pode esquecer que é o espaço que redefine os objetos técnicos, apesar de suas vocações originais. Dessa forma, a técnica é essencialmente humana e sua realização está diretamente relacionada a uma lógica predeterminada.

Parte-se do entendimento que o Estado mantém uma legítima relação dialética com a sociedade capitalista, pois interfere e gera conflitos entre o novo e o velho, entre o externo e o interno, e as forças do mercado e a ação estatal, como expôs Santos (1985). Essa reflexão é fundamental para compreender o papel do Estado frente ao agronegócio, 
por exemplo. Como portador do "novo", o Estado garante a inserção de modernos maquinários, insumos e infraestrutura, e tudo isso tem influência direta com as redes internacionais de comercialização, vinculadas às bolsas de valores (FERREIRA, 2016).

Concorda-se com Mészáros (2011) quando este reflete que o Estado moderno é inconcebível sem o capital e que esse também precisa do Estado como complemento. Assim, o Estado deve ser entendido como parte integrante da própria base material do capital, pois ele contribui significativamente para a formação e consolidação de todas as grandes estruturas produtivas da sociedade, bem como para o seu funcionamento ininterrupto (MÉSZÁROS, 2011).

Hirsch (2005) afirma que mercado e Estado estão relacionados entre si de forma indissolúvel, pois o Estado tem que intervir nas ações do mercado e desta forma acaba, às vezes, por suprimi-lo. Ao mesmo tempo, o Estado segue dependendo fundamentalmente do processo de revalorização capitalista regulado pelo mercado. Hirsch (2005, p. 169) infere que “ [..] o Estado em sua forma social específica só é capaz de se manter na medida que siga sendo garantida a reprodução econômica como processo de revalorização do capital".

De acordo com Castiho e Arrais (2017), grande parte da produção de grãos e minérios oriundos dos estados de Goiás e Mato Grosso, por exemplo, encontra condições limitadas nos principais eixos de escoamento e nos portos do Sudeste do Brasil, o que tem suscitado a necessidade de criação de novos eixos.

É neste contexto de criação de novos eixos de escoamento e circulação da produção, com altos investimentos do Estado, que o projeto de retomada da expansão da Ferrovia Norte-Sul se consolida. A Figura 5 mostra uma síntese da logística de transporte em Goiás, sobretudo no que se refere à principal malha rodoviária atual: BR153, que integra o país de Norte a Sul. É igualmente possível visualizar os principais trechos ferroviários que já estão concluídos e outros que estão em construção, além de objetos técnicos fundamentais para a lógica de escoamento da produção em Goiás, como o Porto Seco, o Aeroporto de cargas de Anápolis, o Poliduto e a Hidrovia em São Simão.

A construção da Ferrovia Norte-Sul iniciou-se no ano de 1987 com um traçado inicial previsto do município de Açailândia (MA) ao de Anápolis (GO). Segundo a Valec (2018), empresa responsável - vinculada ao Ministério do Transporte - pela construção da Ferrovia, o trecho construído entre os municípios de Açailândia (MA) e Estreito (MA), está em operação desde 1996 e apresenta conexão com a Estrada de Ferro Carajás, o que permite o acesso ao Porto de Itaqui, no Maranhão. Já no estado do Tocantins, foram implantados cinco pátios intermodais, nos municípios de: Araguaína, Colinas do Tocantins, Guaraí, Porto Nacional/Palmas e Gurupi. Os principais tipos de cargas que já estão sendo transportadas são: commodities agrícolas, fertilizantes, granéis líquidos, combustíveis, minério de ferro e containers (VALEC, 2013). 


\section{A Logística de Transporte em Goiás}

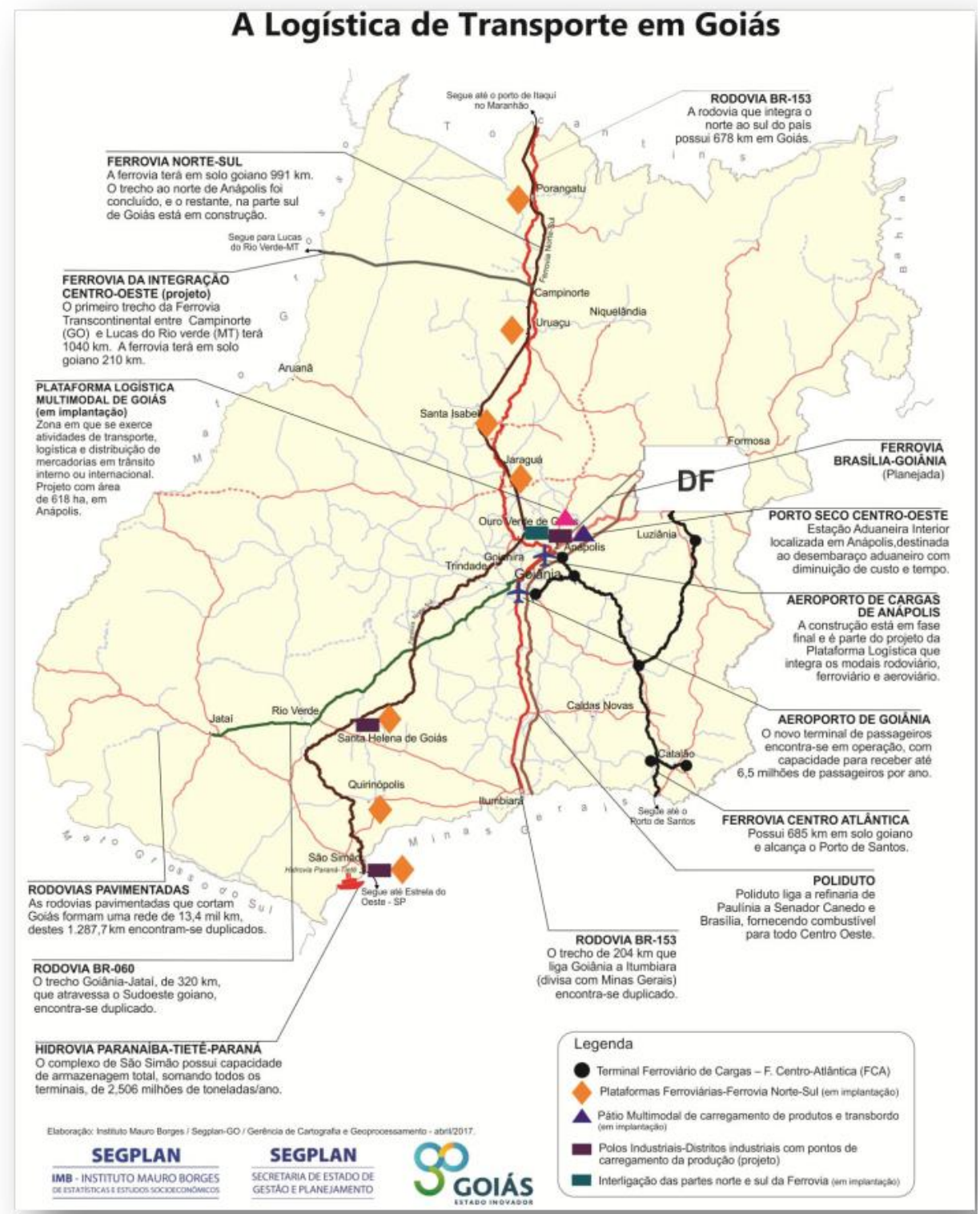

Figura 5. A logística de transporte em Goiás

Fonte: SEGPLAN, 2016. 
Ainda segundo a Valec (2018), o projeto de ampliação da Ferrovia Norte-Sul ocorreu muito depois do início de sua construção. A Lei $n^{\circ} 11.297$, de 09 de maio de 2006, da Presidência da República, incorporou um trecho mais ao norte, do município de Açailândia (MA) até o município de Barcarena (PA). Em 2008, a Lei n ${ }^{\circ} 1.772$ estendeu mais uma vez o traçado da Ferrovia até a cidade paulista de Panorama. A Figura 6 mostra a evolução da carga transportada e a frota de vagões em operação da Ferrovia Norte-Sul no período de 10 anos (2006 a 2016). Verifica-se que a frota total de vagões em operação cresceu ao longo desse período, bem como a carga transportada. Em 2015 foram transportadas 5. 428 (x $10^{3}$ em Tonelada Útil - tu) e até o mês de agosto de 2016, já haviam sido transportadas 4. 189 (x $10^{3}$ em Tonelada Útil - tu), conforme dados da Agência Nacional de Transportes Terrestres (ANTT, 2016).

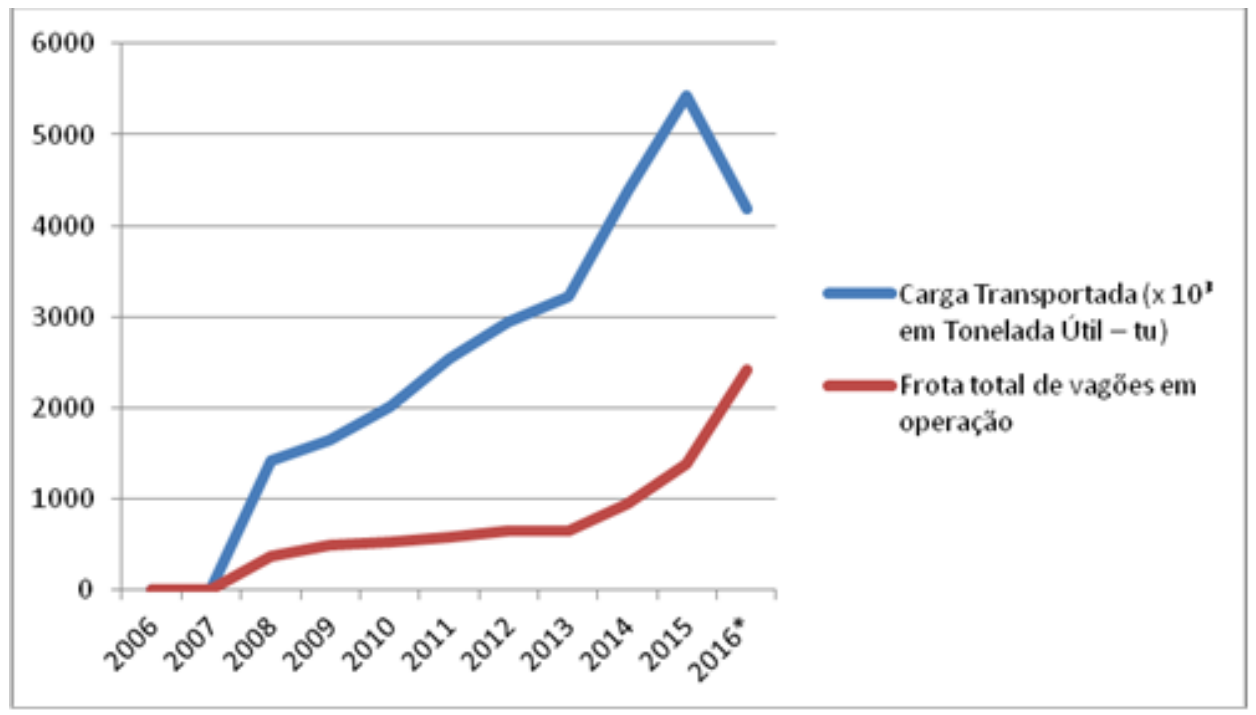

Figura 6. Ferrovia Norte-Sul - Carga transportada e frota de vagões em operação. Legenda: (*) até agosto de 2016.

Fonte: ANTT, 2016.

No estado de Goiás, a Ferrovia Norte-Sul cruza 21 municípios do Centro-Norte goiano: Porangatu, Formoso, Santa Tereza, Estrela do Norte, Mara Rosa, Alto Horizonte, Campinorte, Uruaçu, São Luiz do Norte, Santa Isabel, Rialma, Ceres, Rianápolis, Jaraguá, Jesúpolis, São Francisco do Goiás, Petrolina de Goiás, Ouro Verde, Nerópolis, Campo Limpo e Anápolis. Os municípios citados não são os únicos que sentirão os efeitos gerados pela construção da Ferrovia. Um estudo realizado pela Segplan (2008) mostra que a área de influência da Ferrovia Norte-Sul em Goiás compreende as seguintes regiões de planejamento: Norte Goiano, Noroeste Goiano, Centro Goiano e parte do Nordeste Goiano, Entorno do Distrito Federal e Oeste Goiano; totalizando 130 municípios (CAMPOS; CASTRO, 2014). Goiás contará ainda com 
quatro pátios intermodais nos municípios de Anápolis, Santa Isabel, Uruaçu e Porangatu, que começaram a ser construídos no ano de 2008.

O modal ferroviário caracteriza-se especialmente por sua capacidade de transportar grandes volumes com elevada eficiência energética, sobretudo em deslocamentos a médias e grandes distâncias. Sabe-se também que se comparado ao modal rodoviário, as ferrovias apresentam menor incidênca de acidentes e furtos/roubos (VALEC, 2018). As ferrovias transportam principalmente produtos siderúrgicos, grãos, minério de ferro, cimento e cal, adubos e fertilizantes, derivados de petróleo, calcário, carvão mineral e clinquer; e, contêineres.

De modo geral, para o estado de Goiás, os setores vinculados ao agronegócio e à produção de minérios serão os mais contemplados pela Ferrovia Norte-Sul. Goiás é um dos maiores arrecadadores da exploração de recursos minerais no Brasil. De acordo com o relatório realizado pelo Departamento Nacional de Produção Mineral (DNPM, 2013), Goiás corresponde ao terceiro estado da federação em maior arrecadação em Compensação Financeira pela Exploração de Recursos Minerais (CFEM), antecedido somente pelos estados de Minas Gerais e Pará (Tabela 02).

Tabela 2. Estados que mais arrecadaram CFEM - 2013

\begin{tabular}{c|l|c}
\hline \multicolumn{2}{|c|}{ Estado } & Recolhimento CFEM (R\$) \\
\hline 1 & Minas Gerais & $1.204 .716 .774,07$ \\
\hline 2 & Pará & $803.855 .053,59$ \\
\hline 3 & Goiás & $68.007 .333,02$ \\
\hline 4 & São Paulo & $55.493 .568,26$ \\
\hline 5 & Bahia & $47.510 .219,70$ \\
\hline 6 & Mato Grosso do Sul & $28.590 .067,53$ \\
\hline 7 & Santa Catarina & $18.360 .952,43$ \\
\hline 8 & Sergipe & $16.235 .105,34$ \\
\hline 9 & Mato Grosso & $16.209 .034,26$ \\
\hline 10 & Rio Grande do Sul & $15.754 .891,56$ \\
\hline
\end{tabular}

Fonte: Departamento Nacional de Produção Mineral (DNPM) / Diretoria de Procedimentos Arrecadatórios (DIPAR).

Para as regiões Centro e Norte de Goiás destacam-se, nessa dinâmica, Niquelândia, Alto Horizonte, Barro Alto, Crixás e Minaçu. Os municípios citados são destaques na extração de Níquel, principalmente em Niquelândia e Barro Alto; concentrando cobre e ouro, em Alto Horizonte; e ouro e prata, em Crixás. Minaçú foi por muitos anos o maior produtor de amianto crisotila do Brasil, contudo, em novembro de 2017, o Supremo Tribunal Federal (STF) tomou a decisão de proibir o uso do amianto no Brasil. No dia 29 de novembro de 2017, o Plenário já havia declarado a inconstitucionalidade de dispositivo da Lei Federal 9.055/1995 que autorizava a extração, industrialização, comercialização e a distribuição na variedade Crisotila $(\mathrm{O}$ POPULAR, 2018). 
Apesar do clima de incertezas, sobretudo econômico-financeiras com a proibição da extração de amianto em Minaçu, está em processo de implantação a extração de Terras Raras ${ }^{2}$ nesse município, por meio da Mineração Serra Verde, que deverá em 2019 ou 2020, iniciar a extração. Até o momento, o grupo que controla a Serra Verde, a Mining Ventures Brasil, já investiu na empresa cerca de US\$ 60 milhões, de um total de US\$ 120 milhões investidos em atividades de exploração mineral no País (BRASIL MINERAL, 2018).

Assim, em síntese, além da relevante extração de minérios presente principalmente nos municípios do Norte Goiano, há também uma expressiva produção de cana-de-açúcar no Centro-Norte Goiano, particularmente nos municípios de Goianésia, Carmo do Rio Verde, Itapaci, Itapuranga, Santa Isabel, São Luiz do Norte, Nova Glória e Uruaçu. Há nessa região 10 usinas canavieiras implantadas que são responsáveis por produzir etanol, açúcar (variados tipos), álcool em gel, levedura, e outros derivados. No entanto, uma delas está com a licença suspensa temporariamente,

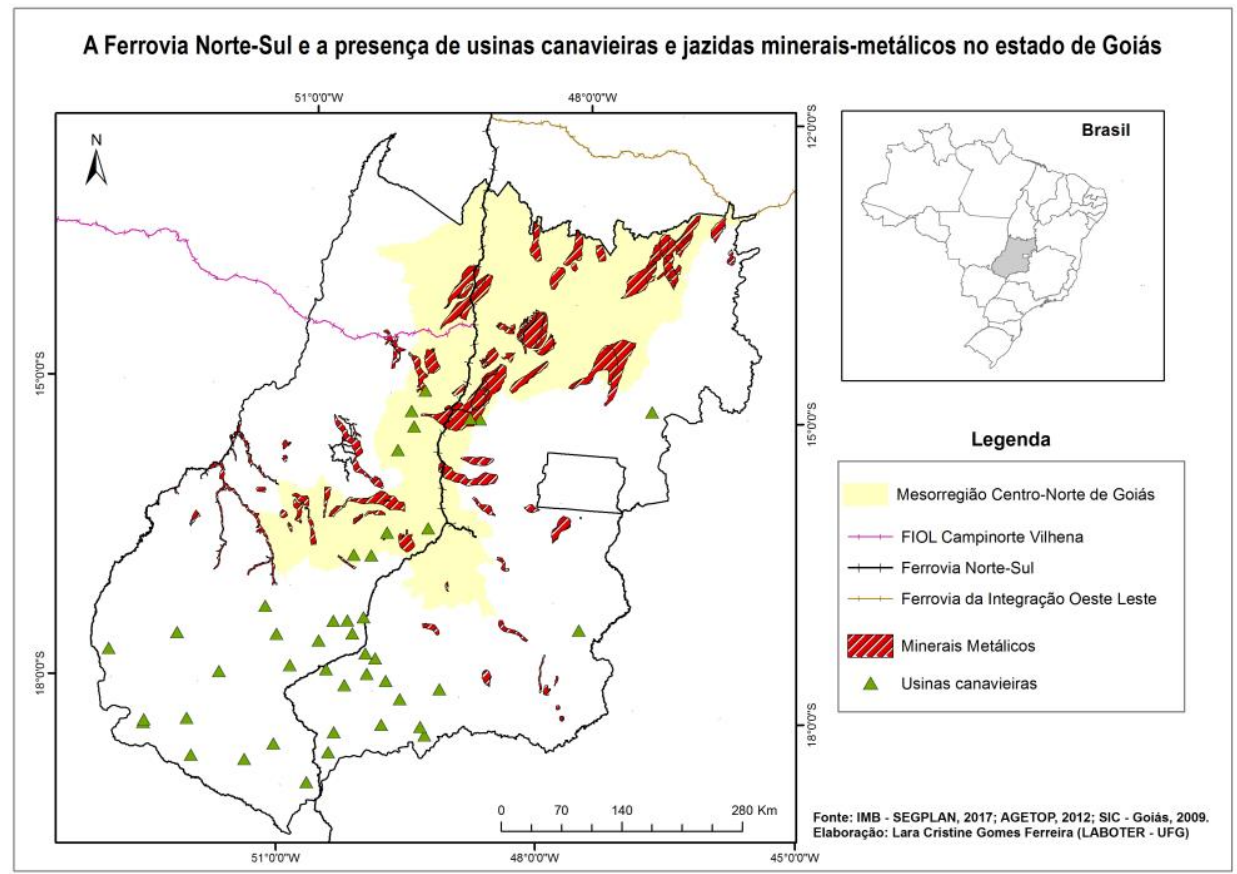

Figura 07. A presença das usinas canavieiras e as jazidas minerais-metálicos em Goiás. Fonte: Ferreira (2018).

${ }^{2}$ O depósito da Serra Verde possui recursos de 911 milhões de toneladas, com 0,12\% de óxidos de terras raras, principalmente Prazeodímio, Neodímio e Térbio. 
A Figura 07 traz a tentativa de apresentar um mapa-síntese do estado de Goiás, com ênfase no Centro-Norte Goiano, mostrando a presença da usinas canavieiras, as principais jazidas de minerais-metálicos e o traçado da Ferrovia Norte-Sul atravessando todo o território. Nela se percebe claramente a intensa presença das agroindustrias sucroenergéticas e a concentração das jazidas minerais-metálicos, principalmente no Norte do estado de Goiás.

Diante do exposto, infere-se que a Ferrovia Norte-Sul atravessa uma série de municípios estratégicos em Goiás. Destaca-se, portanto, o de Anápolis (no Centro Goiano) que possui um Porto Seco e um Distrito Agroindustrial (DAIA) muito importantes financeiramente e economicamente para o Centro-Oeste brasileiro. A Figura 8 apresenta o trecho urbano da Ferrovia Norte-Sul, visitado durante atividade de campo no mês de agosto de 2018. Ela mostra também algumas casas construídas próximas ao trecho da Ferrovia. Vale destacar que, neste exato local, várias casas foram desapropriadas para dar lugar aos trilhos da Ferrovia Norte-Sul em Anápolis.

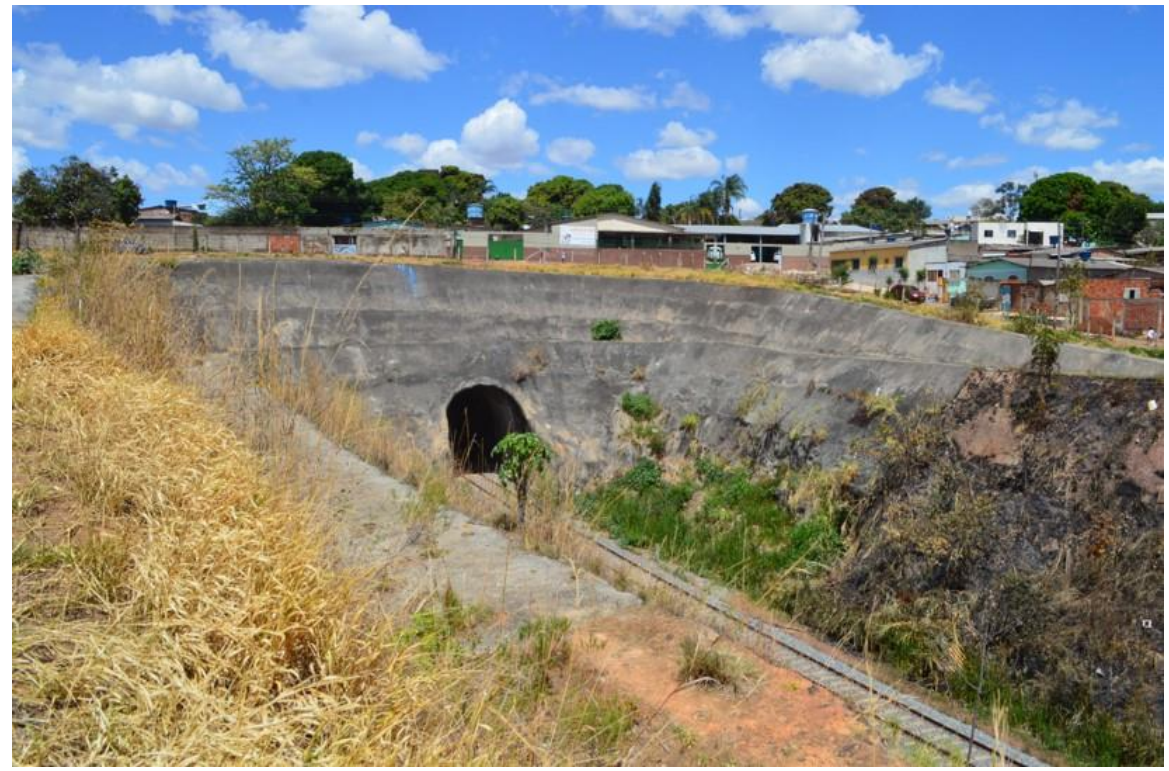

Figura 8. Trecho urbano da Ferrovia Norte-Sul em Anápolis, Goiás.

Foto: Os autores (2018).

Ressalta-se também que, inegavelmente, a Ferrovia Norte-Sul foi pensada para transportar produtos e mercadorias, o que é fruto da lógica do capital agronegocista brasileiro. Assim, para as regiões estudadas, o açúcar será, sem dúvida, a principal 
commodity a ser transportada, visando o mercado internacional. Cita-se, portanto, o município de Ceres, que apresenta, somente nessa microrregião, sete empreendimentos sucroenergéticos em pleno funcionamento, além de grandes extensões de terra em produção canavieira. Entretanto, Goianésia é o que mais se destaca na lógica do capital canavieiro. Somente nesse município são três usinas em funcionamento, sendo que a Jalles Machado corresponde a uma das usinas mais produtivas do estado de Goiás, inclusive com capital internacional e com vários produtos sendo comercializados com o mercado externo, sobretudo com os Estados Unidos e países da Europa e Ásia (exportação de açúcar - cristal e orgânico, principalmente).

Ao longo da Ferrovia Norte-Sul serão construídos uma série de pátios. Salientase aqui o pátio previsto para ser construído no município de Santa Isabel, também pertencente à microrregião Ceres e localizado a cerca de 40 quilômetros de Goianésia. Além da proximidade com as usinas de Goianésia, cabe sublinhar que Santa Isabel também está inserida na lógica canavieira, sendo um dos três municípios com maior produção de cana-de-açúcar da microrregião Ceres (FERREIRA, 2016).

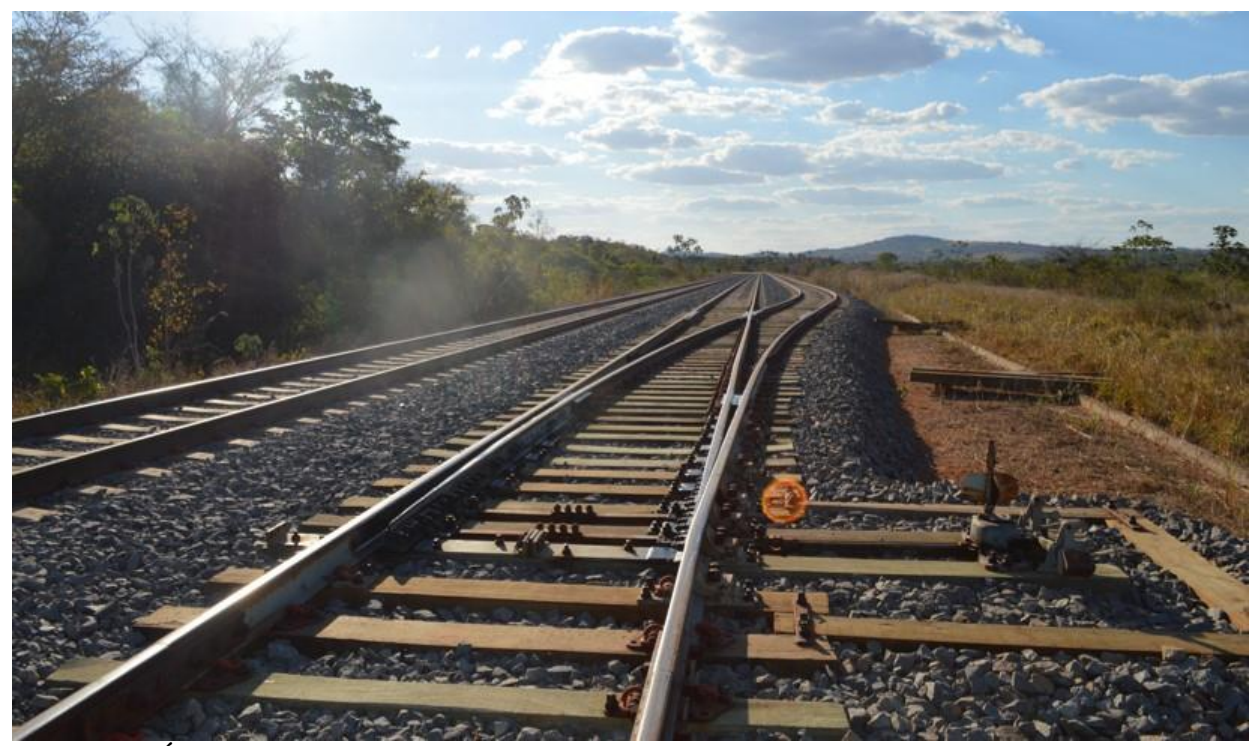

Figura 9. Área destinada à construção do Pátio de Santa Isabel da FNS.

Foto: Os autores (2018).

O pátio previsto para Santa Isabel ainda está somente no papel, o que se observa in loco é a área destinada à sua construção, com a presença do que será a área de carregamento e cruzamento (Ver Figura 9). Ela corresponde a cerca de 20 alqueires e, 
mesmo assim, já carrega as consequências da lógica capitalista abordada durante todo o artigo. Essa área em Santa Isabel possui um assentamento de Reforma Agrária, o que gerou a desapropriação de famílias para a construção dos trilhos da ferrovia e do futuro pátio.

Por fim, ressalta-se que a construção dos pátios, ao longo da Ferrovia NorteSul, poderá atrair importantes polos industriais e contar com áreas para manobras e cruzamento de veículos ferroviários, depósitos, armazéns, armazenamento de mercadorias e serviços logísticos. Como consequência, será possibilitada uma maior dinâmica econômica, fluidez na circulação da produção do agronegócio em geral e da dinâmica canavieira em particular, no Centro e Norte Goiano, circulando os produtos dessas regiões para os mercados consumidores.

\section{Considerações finais}

A Ferrovia Norte-Sul é um projeto nacional antigo, mas que ainda apresenta grandes entraves financeiros, estruturais e políticos para sua efetivação. A proposta é que a Ferrovia Norte-Sul conecte cerca de 10 estados brasileiros, de Norte a Sul do país, no intuito de dinamizar e agilizar a circulação dos produtos das áreas produtoras brasileiras até os principais portos, visando a exportação.

Apresentou-se neste artigo as características centrais de produção das regiões Centro e Norte do estado de Goiás, bem como a lógica agroexportadora e de extração de minérios presente nessas mesorregiões goianas. Partiu-se da premissa de que o Estado é um importante agente para o funcionamento da sociedade capitalista, conforme as discussões propostas por Harvey (2005). Atualmente, há poucos aspectos da produção e do consumo que não são afetados, direta ou indiretamente, pelas políticas do Estado. Dessa forma, quando se observa os aspectos sociais de maneira mais aproximada, notase que a modernização do território, evidenciada por Castilho (2014), acaba por privilegiar as grandes empresas e corporações territorializadas no Brasil, de modo geral, e no estado de Goiás, de modo particular.

Assim, fica evidente que o cenário de construção e efetivação da Ferrovia Norte-Sul configura-se para atender à lógica do agronegócio brasileiro, principalmente do setor de grãos, com grande destaque para a região Centro-Oeste do Brasil, no intuito de integrar o território nacional e reduzir os custos das commodities destinadas à exportação, como bem refletiu Campos e Castro (2014).

No que tange ao objeto de estudo, evidenciou-se que a relação entre a Ferrovia Norte-Sul e o Centro-Norte do estado de Goiás está diretamente vinculada à lógica da produção canavieira da região, com a presença de 10 empreendimentos sucroenergéticas. Além da forte presença de jazidas de minerais, bem como de grandes mineradoras, muitas com capital estrangeiro, localizadas principalmente na mesorregião Norte de Goiás. 
Ressalta-se que a intenção da Ferrovia Norte-Sul nunca foi integrar a pequena produção - da agricultura familiar, por exemplo, muito menos de transportar pessoas, o que vai na contramão da lógica de integração de modais, já presente em países 'desenvolvidos' ou 'em desenvolvimento', dos quais o Brasil compartilha patamares semelhantes de desenvolvimento econômico-industrial, mas, distante em questões sociais. Desta forma, não é incomum verificar na paisagem regional efeitos oriundos dessa lógica exclusivamente capitalista que estão visivelmente materializadas nessa paisagem. Verificou-se desapropriações, expropriações e praticamente nenhum tipo de política ou programa de inclusão aos pequenos produtores ou com a finalidade de ampliar os usos dados e pensados à Ferrovia Norte-Sul. Reitera-se, portanto, a dimensão política da técnica e os usos corporativos do território legitimados tanto pela lógica privada do mercado, quanto por meio de financiamentos e ações oriundas do Estado.

\section{Referências}

ARRAIS, T. A. A produção do território goiano: economia, urbanização, metropolização. Goiânia: Ed. UFG, 2013.

BRASIL. Ministério dos Transportes. Transportes no Brasil - síntese histórica. 2012. Disponível em: <http://www.transportes.gov.br/index/conteudo/id/60924>. Acesso em: 01 jun. 2018.

BRASIL. Ministério do Planejamento. $6^{\circ}$ Balanço do PAC 2015-2018 (Julho - Dezembro 2017). Disponível em:

<http://pac.gov.br/pub/up/relatorio/11fbe9b2f7cbecb3ec5c1f9f67b5f3be.pdf>. Acesso em: 10 jul. 2018.

BRASIL MINERAL. Disponível em: <http://www.brasilmineral.com.br/noticias/brasilter\%C3\%A1-dois-novos-projetos-de-\%C3\%B3xidos>. Acesso em: 01 jun. 2018.

BENAKOUCHE, T. Tecnologia é sociedade: contra a noção de impacto tecnológico. In: DIAS, L.C.; SILVEIRA, R. L. L. (Org.). Redes, sociedades e territórios. Santa Cruz do Sul: EdUnisc, 2005.

CASTILHO, D. (Org.). Cerrados: perspectivas e olhares. Goiânia: Editora Vieira, 2010.

CASTILHO, D. Modernização territorial e redes técnicas em Goiás. 2014. 221 f. Tese (Doutorado) - Programa de Pós-Graduação em Geografia do Instituto de Estudos Socioambientais, Universidade Federal de Goiás, Goiânia, 2014.

CASTILHO, D.; ARRAIS, T. A. A Ferrovia Norte-Sul e a economia regional do centronorte do Brasil. Revista Sociedade \& Natureza, Uberlândia, v. 29, n. 2, p. 209-228, maio/ago. 2017.

CASTRO, A. B. de. Planejamento: avaliação crítica e redefinição institucional. São Paulo em Perspectiva, São Paulo, v. 5, n. 4, p.13-17, out./dez. 1991. 
CHAUL, N. F . Caminhos de Goiás: da construção da decadência aos limites da modernidade. Goiânia: Editora UFG: Editora UCG, 1997.

DIAS, L. C. Redes de Informação, grandes organizações e ritmos de modernização. Etc... Espaço, Tempo e Crítica, v. 1, n. 2, jun. 2007.

ESTEVAM, L. No Cerrado das tropas e boiadas (ensaio histórico - literário). In GOMES, H. (Org). Universo do Cerrado. Goiânia: Editora da UCG. 2008. (v. 2).

FERREIRA, L. C. G. As paisagens regionais na Microrregião Ceres (GO): das colônias agrícolas nacionais ao agronegócio sucroenergético. 2016. 296 f. Tese (Doutorado em Geografia) - Universidade de Brasília, Brasília, 2016.

FISCHER, A. Indústria, ordenamento do território e transportes: a contribuição de André Fischer. Organização Olga Lúcia C. Firkowski e Eliseu S. Sposito. São Paulo: Expressão Popular, 2008.

FRAGA, N. C. Território, região, poder e rede: olhares e possibilidades conceituais de aproximação. Relações Internacionais no Mundo Atual, Curitiba, n. 7, p. 9-31, 2007.

GOIÁS (Estado). Secretaria de Estado de Gestão e Planejamento. Superintendência de Estatísticas, Pesquisa e Informações Socioeconômicas. Goiás em dados - 2011. Goiânia, 2018.

GOIÁS (Estado). Secretaria de Estado de Gestão e Planejamento. Superintendência de Estatísticas, Pesquisa e Informações Socioeconômicas. PIB dos municípios goianos - 2017. Goiânia, 2018.

HARVEY, D. A produção capitalista do espaço. São Paulo: Annablume, 2005.

HIRSCH. J. ¿Qué significa estado? Reflexiones acerca de la Teoría del Estado Capitalista. Revista de Sociologia Política, Curitiba, n. 24, p. 165-175, jun. 2005.

IBGE. Produção da Pecuária Municipal 2016. Rio de Janeiro: IBGE, 2017.

IBGE. Cadastro Central de Empresas 2016. Rio de Janeiro: IBGE, 2018.

JARDIM, M. C.; SILVA, M. R. Programa de Aceleração do Crescimento (PAC): Neodesenvolvimentismo. São Paulo: Ed. Unesp, 2015.

MARTINS, J. de. S. Fronteira: a degradação do outro nos confins do humano. São Paulo: Hucitec, 1997.

MÉSZÁROS, I. Para além do capital: rumo a uma teoria da transição. Tradução Paulo Cezar Castanheira, Sérgio Lessa. 1.ed. revista. São Paulo: Boitempo, 2011.

O POPULAR (Jornal). Minaçu já sente efeitos da decisão do STF que proíbe o amianto no País. O Popular, Goiânia, 30 nov. 2017. Disponível em: < https://www.opopular.com.br/editorias/economia/mina\%C3\%A7u-j\%C3\%A1-sente-efeitos- 
da-decis\%C3\%A3o-do-stf-que-pro\%C3\%ADbe-o-amianto-no-pa\%C3\%ADs-diz-prefeito1.1406933>. Acesso em: 10 jul. 2018.

RAFFESTIN, C. Por uma geografia do poder. São Paulo: Ática, 1993.

SANTOS, M. Natureza do espaço: técnica e tempo, razão e emoção. São Paulo: Editora da USP, 2006.

TEIXEIRA NETO, A. Pequena história da agropecuária goiana (o ouro acabou? Viva o boi!/ o ouro se foi? Chegou o boi!). Goiânia: Observatório Geográfico de Goiás, 2008.

VALEC. Valec construções eferrovias S/A. Disponível em <http://www.valec.gov.br/>. Acesso em: 28 jun. 2018.

Agradecimentos: Este artigo foi desenvolvido no âmbito do projeto "A rede ferroviária em Goiás: análise e mapeamento da dinâmica econômica regional e da urbanização entre 1911 e 2014", aprovado pela chamada MCTI/Universal 14/2014 do Conselho Nacional de Desenvolvimento Científico e Tecnológico (CNPq), a quem os autores registram seus agradecimentos.

\section{Lara Cristine Gomes Ferreira}

Doutora em Geografia pela Universidade de Brasília, com estágio doutoral (sanduíche / bolsa CAPES), na Universidade de Santiago de Compostela, Galícia / Espanha. É geógrafa e mestra em Geografia pela Universidade Federal de Goiás. Atualmente é geógrafa do Laboratório de Estudos e Pesquisas das Dinâmicas Territoriais do Instituto de Estudos Socioambientais da Universidade Federal de Goiás, e integrante do Grupo de Estudos sobre Redes e Produção do Território.

Endereço: Laboter/IESA/UFG, Av. Esperança, s/n, Samambaia, Goiânia (GO). CEP: 74001-97.

E-mail: laracristineufg@yahoo.com.br

\section{Caio César Alencar de Sena}

Doutorando e Mestre em Geografia pela Universidade Federal de Goiás (UFG). Graduado em Geografia pela UFG com 1 ano de intercâmbio na Katholische Universität de EichstättIngolstadt (KUEI), na Alemanha. Atualmente é professor efetivo da Rede Municipal de Educação de Goiânia e professor substituto no Instituto de Estudos Socioambientais da UFG, onde integra o Grupo de Estudos sobre Redes e Produção do Território. Endereço: Laboter/IESA/UFG, Av. Esperança, s/n, Samambaia, Goiânia (GO). CEP: 74001-97.

E-mail: caiosenageo@gmail.com

Recebido para publicação em fevereiro de 2018 Aprovado para publicação em junho de 2018 